\title{
Rola rodziny w kształtowaniu ekspresji emocji
}

Dziecko wita ten świat płaczem. To pierwsza po urodzeniu naturalna forma ekspresji emocji, które będą towarzyszyć temu nowonarodzonemu człowiekowi przez całe życie. W rodzinie, przedszkolu, szkole, na katechezie, w relacjach międzyludzkich będzie się on uczyć rozpoznawać, nazywać i wyrażać własne emocje i uczucia. W niniejszym artykule podejmuję tematykę emocji i uczuć w życiu człowieka, a zwłaszcza roli rodziny w wychowaniu emocjonalnym dziecka i uczeniu się przez dziecko, nastolatka i człowieka dorosłego różnych form i sposobów ekspresji emocji.

\section{Emocje i uczucia w życiu człowieka}

Stany emocjonalne, do których należą emocje i uczucia, odzwierciedlają, opisują to, co człowiek przeżywa, co się z nim dzieje. Terminologiczne odróżnienie emocji od uczuć nie zawsze okazuje się proste. Zimbardo, referując dotychczasowe ustalenia, definiuje emocje jako „złożony zespół zmian ciele- 
snych i psychicznych, obejmujących pobudzenie fizjologiczne, uczucia, procesy poznawcze i reakcje behawioralne wykonywane w odpowiedzi na sytuację spostrzeganą jako ważna dla danej osoby"1. Pobudzenie fizjologiczne to zmiany hormonalne, neuronalne, trzewiowe i mięśniowe. Uczucia to zarówno ogólne stany afektywne (pozytywne lub negatywne), jak i specyficzne tony uczuciowe takie jak radość czy wstręt. Do procesów poznawczych związanych z emocjami zalicza interpretacje, wspomnienia i oczekiwania, natomiast zewnętrzne reakcje behawioralne przyjmują formę ekspresyjną (płacz, śmiech) bądź formę ukierunkowania na działanie (np. wołanie o pomoc) ${ }^{2}$. Formy te bywają nazywane odpowiednio reakcjami ekspresyjnymi i czynnościami emocjonalnymi ${ }^{3}$. W literaturze, zwłaszcza popularnonaukowej, można znaleźć interpretacje, które emocje traktują jako stany powiązane bardziej z organizmem i sferą somatyczną, gdyż towarzyszą im obserwowalne zjawiska somatyczne, np. gęsia skórka, odczucie zimna lub gorąca, zblednięcie lub zaczerwienienie się, szybsze bicie serca i inne. Uczucia natomiast byłyby bardziej duchowe, mniej powiązane ze sferą somatyczną ${ }^{4}$. Inne spojrzenie za emocje bierze wszystko, co przeżywamy, a uczucia za stany emocjonalne specyficzne tylko dla człowieka ${ }^{5}$. Idąc za tą propozycją, dokonuję pewnego uproszczenia, mówiąc o stanach emocjonalnych ogólnie jako o emocjach. Ich bogactwo pozwala wyodrębniać emocje i uczucia wyraźnie pozytywne (np. radość, szczęście, miłość, zadowolenie, dumę, oczarowanie, euforię, przyjemność, ulgę, wdzięczność, sympatię, odprężenie), emocje wyraźnie negatywne (np. złość, gniew, nienawiść, wściekłość, smutek, lęk, strach, przygnębienie, zmartwienie, udrękę, zdenerwowanie, rozdrażnienie, niepokój, obawę, przerażenie, rozczarowanie, niesmak, wstyd, niechęć, nudę, niezadowolenie, żal - pretensję do kogoś - przykrość, ból fizyczny i psychiczny, wstręt, obrzydzenie, zawód, rozgoryczenie, zmartwienie), ale też stany emocjonalne niemające wyraźnego pozytywnego lub negatywnego zabarwienia lub uzyskujące to zabarwienie w sposób zmienny, zależnie od okoliczności

P. G. Zimbardo, R. J. Gerrig, Psychologia i życie, tłum. E. Czerniawska, Warszawa 2002, s. 473.

P. G. Zimbardo, R. J. Gerrig, Psychologia i życie, s. 473.

3 Podstawy psychologii. Podręcznik dla studentów kierunków nauczycielskich, red. W. Pilecka, B. Grudkowska, L. Wrona, Kraków 2000, s. 237-238.

$4 \quad$ W. Szewczyk, Rozumieć siebie i innych. Zarys psychologii, Tarnów 2002, s. 117.

5 M. Dziewiecki, Emocje. Krzyk do zrozumienia, Nowy Sącz 2018, s. 15. 
(np. zaskoczenie, zdziwienie, zazdrość, onieśmielenie, tęsknotę, zaciekawienie, współczucie, żal - użalenie się nad kimś - wzruszenie, napięcie).

Znaczenie terminu „emocje” jest potrójne. Pierwsze dotyczy syndromu emocjonalnego rozumianego jako efekt potocznego doświadczenia, z którego wynika, jak i co powinna robić osoba przeżywająca daną emocję, np. gniew. Drugie dotyczy stanu emocjonalnego, czyli krótkotrwałej i odwracalnej dyspozycji do reagowania zgodnie z syndromem emocjonalnym. Trzecie znaczenie dotyczy reakcji emocjonalnej, czyli bieżącego i zmiennego zbioru ujawnianych w danym stanie emocjonalnym reakcji, np. wyrazu twarzy, symptomów fizjologicznych, zachowań zewnętrznych i doznań subiektywnych. To rozróżnienie jest przydatne do lepszego rozumienia efektów kontroli emocji, czyli tego, co człowiek robi ze swoimi emocjami, czy i jak je wyraża, do jakich reakcji i zachowań ma dyspozycję. Okazuje się bowiem, że zmiana emocji pod wpływem ich kontroli zależy od tego, czy kontrolę tę odnosimy do syndromu emocjonalnego, do stanu emocjonalnego czy do reakcji emocjonalnej ${ }^{6}$. Syndrom emocjonalny nie podlega kontroli osobistej, bo jest to pewien model wypracowany przez środowisko. Sporo reakcji emocjonalnych często wynika z organizmu, więc bezpośredni wpływ człowieka na nie jest też niewielki. Niektóre reakcje emocjonalne w postaci zachowań, gestów, wypowiedzi są jednak efektem wolnego działania człowieka i podlegają jego osobistej kontroli. Od człowieka wiele zależy również w obszarze stanu emocjonalnego, bo to dana osoba decyduje, do jakich zachowań i reakcji jest gotowa. Świadome zabiegi wychowawcze, formacyjne czy terapeutyczne będą się więc głównie odnosić do reakcji emocjonalnych będących wolnym działaniem człowieka oraz do dyspozycji do określonych działań.

Wpływ kontroli emocji na ich zmianę zależy też od tego, do której z reguł emocji odnosi się ta kontrola. Reguły rządzące emocjami są trojakiego typu: konstytutywne, regulacyjne i proceduralne. Reguły konstytutywne niejako definiują daną emocję i pozwalają ją odróżnić od innych. Ich złamanie prowadzi do błędnego odczytania danej emocji i odczytania jej jako innej emocji (np. złamanie reguły konstytutywnej gniewu może sprawić, że gniew zostanie rozpoznany jako sadyzm lub okrucieństwo). Reguły regulacyjne podają ogólne uzasadnienia dla posługiwania się emocjami w różnych

$6 \quad$ J. R. Averill, Nieodpowiednie i odpowiednie emocje, w: Natura emocji. Podstawowe zagadnienia, red. P. Ekman, R. J. Davidson, tłum. B. Wojciszke, Gdańsk 1999, s. 227-228. 
sytuacjach. Złamanie tych reguł powoduje, że dana emocja zostanie co prawda właściwie odczytana, ale nieuzasadniona w danym kontekście (np. rozpoznanie gniewu, gdy nie ma się o co gniewać - emocja nieadekwatna do sytuacji). Reguły proceduralne określają konkret strategii wyrażenia emocji, sposobu ekspresji emocji. Złamanie takich reguł powoduje, że nawet gdy reakcja emocjonalna jest adekwatna do sytuacji, właściwa, zostanie odczytana jako niewłaściwie wykonana, wyrażona w niewłaściwy sposób. Warto też zauważyć, że zmiana reguł emocji pociąga za sobą zmianę sposobów ich przejawiania, np. jeśli ukształtowana środowiskowo, historycznie i kulturowo konstytutywna reguła emocji ulegnie zmianie, nastąpi również konstruowanie nowych syndromów emocjonalnych. Niekiedy na skutek błędów wychowawczych, poznawczych czy innych czynników osoba konstruuje własne reguły konstytutywne emocji, które znacznie odbiegają od reguł konstytutywnych funkcjonujących w danym społeczeństwie, a co za tym idzie - wyraża swoje emocje, potrzeby i pragnienia w sposób specyficzny, odmienny, często zaburzony.

Te uwagi pozwalają zauważyć, że reguły regulacyjne i proceduralne odgrywają znaczącą rolę w kontroli emocji. Kontrola ta oznacza, że osoba potrafi reagować emocjonalnie w taki sposób, w jaki chce, zarówno ujawniając, jak i hamując daną reakcję. Brak kontroli emocji może oznaczać nieumiejętność zarówno powstrzymania ekspresji emocji, jak i jasnego i skutecznego wyrażenia emocji pożądanych w danych okolicznościach ${ }^{7}$. W tych kontekstach wydają się całkowicie uzasadnione zabiegi wychowawcze, formacyjne czy terapeutyczne w kierunku wypracowywania umiejętności kontroli emocji w odniesieniu do wszystkich wymienionych wyżej reguł, zwłaszcza reguł regulacyjnych i proceduralnych, aby osoba nie tylko wyrażała emocje tak jak chce, ale także żeby sposoby ekspresji emocji mieściły się w ramach funkcjonujących w danej kulturze zasad. Podkreślić jednak trzeba, że pojęcie kontroli emocji (rozumianej zarówno jako automatyczna regulacja przebiegu emocji, jak i jako podmiotowa samokontrola emocji) jest szersze niż ekspresja emocji, inaczej mówiąc - regulacja emocji dotyczy wpływu na pojawianie się emocji, ich przebieg, konsekwencje oraz zewnętrzną ekspresję ${ }^{8}$.

J. R. Averill, Nieodpowiednie i odpowiednie emocje, dz. cyt., s. 228-229.

8 D. Doliński, Emocje, poznanie i zachowanie, w: Psychologia. Podręcznik akademicki, t. 2, Psychologia ogólna, red. J. Strelau, Gdańsk 2010, s. 381-384. 


\section{Ekspresja emocji w perspektywie rozwojowej i rodzinnej}

Zagadnienie ekspresji emocji wpisuje się w szersze spektrum tematyki rozwoju i wychowania emocjonalnego dzieci, młodzieży, ale też i człowieka dorosłego. Ekspresję emocji można definiować jako „wszelkie sygnały (zmiany w wyglądzie organizmu, ruchy i dźwięki) emitowane przez jednostkę, będące dla kogoś innego wskazówką przeżywania przez tę osobę określonych emocji”" . Obserwacja życia i literatura przedmiotu akcentuje niezastąpioną rolę rodziny w kształtowaniu emocjonalności dziecka, w tym również ekspresji jego emocji. Rozwój dzieci pozbawionych miłości jest zazwyczaj zakłócony i nieprawidłowy. Odrzucenie emocjonalne dziecka, styl wychowania, w którym dominują ciągłe pretensje, nieprzewidywalność, nadmierna kontrola i szantaż emocjonalny, albo przeciwnie - liberalny styl wychowania - to czynniki zmniejszające zdolność dzieci do poradzenia sobie z problemami i pokonywania własnych lęków. Nie brak rodziców, którzy ignorują uczucia swoich dzieci, traktują je jako coś mało znaczącego. Inni, choć zdają sobie sprawę z uczuć dzieci, za wszelką cenę chcą sprawić, by dziecko przestało być smutne, obrażone czy zdenerwowane, zamiast szukać rozwiązania problemu u jego korzeni. Zdarzają się też rodzice autorytarni, którzy wobec wyrażanych przez dzieci uczuć czy emocji podnoszą głos, nie pozwalają dzieciom się wypowiedzieć, tak by te mogły wyjaśnić sytuację, tym samym niszczą klimat zaufania, fundamentalny dla właściwego rozwoju dziecka i wychowania emocjonalnego. Prawidłowe podejście do wychowania prezentują ci rodzice, którzy uczucia swoich dzieci traktują poważnie, dokładają starań, żeby dobrze je poznać, tworzą klimat zaufania, który ułatwia otwieranie się dzieci i jest zachętą do zwierzeń. Rodzice ci zdają sobie sprawę, że już samo wypowiadanie uczuć i emocji przynosi ulgę i ukojenie, a dziecko, które czuje się wysłuchane i zrozumiane, nie tylko chętnie będzie powracać do takiego stylu rozmowy, ale też kształtuje gotowość wsłuchiwania się i umiejętność rozumienia uczuć i emocji innych ${ }^{10}$.

Obserwacja dzieci pod kątem ekspresji emocji pozwala zauważyć, że w poszczególnych fazach rozwojowych pojawiają się coraz to nowe emocje

9 D. Doliński, Ekspresja emocji. Emocje podstawowe i pochodne, w: Psychologia. Podręcznik akademicki, dz. cyt., s. 351.

10 A. Aguilo, Wychowywać uczucia, tłum. K. Radzikowska, Ząbki 2009, s. 162-163, 178-180. 
i coraz bogatszy wachlarz ich ekspresji. Występujące u niemowląt reakcje mimiczne interpretowane jako wyraz zaskoczenia i radości pojawiały się również w takich sytuacjach, w których dzieci te prawdopodobnie nie doświadczały takich emocji. Podobnie reakcje mimiczne odpowiadajcie strachowi, gniewowi i smutkowi dopiero w trakcie dalszego rozwoju zostają powiązane $\mathrm{z}$ odpowiadającymi im emocjami ${ }^{11}$. Istnieje przekonanie, że reakcje emocjonalne małych dzieci są wynikiem modelowania, a niemowlęta dopasowują się do obserwowanych reakcji afektywnych - najczęściej matki - już od 3. miesiąca życia. Dzieci starsze uczą się nazywania emocji poprzez codzienne doświadczenia. Rodzice nazywają ich emocje w wypowiedziach typu: „wyglądasz tak, jakbyś się gniewał”. Reakcje afektywne dość wiernie odzwierciedlają emocje najmłodszych, ale z biegiem czasu dzieci coraz bardziej kontrolują ekspresję swoich emocji i to, co wyrażają na zewnątrz, niekoniecznie pokazuje to, co faktycznie czują, ale to, co jest zawarte w obowiązujących w danej kulturze oczekiwaniach społecznych co do wyrazu emocji. Przykładowo chłopcy dość często uczą się, że wyrażanie przez nich strachu czy bólu jest niewłaściwe, niemęskie i z tego powodu będą powstrzymywać wyrażania tych emocji ${ }^{12}$.

W miarę jak dziecko dorasta, na skutek zmiany stawianych sobie celów, relacji społecznych i rozumienia innych ludzi, zmieniają się też warunki i okoliczności, które wzbudzają w młodej osobie poszczególne emocje, również te podstawowe. Pojawiają się też nowe emocje: duma, poczucie winy, wstyd, zazdrość, zadowolenie, zawiść i zakłopotanie, a sposób wyrażania emocji zaczyna się wiązać z respektowaniem i przestrzeganiem norm ważnych dla innych, oczekiwaniem aprobaty ze strony innych oraz rozwojem pojęcia „ja”. Badacze akcentują rolę rosnącej dojrzałości poznawczej dziecka w rozumieniu sytuacji społecznych i pojawiających się nowych emocji. Badania rozwoju emocjonalnego uwzględniające kontekst rodzinny pokazują, że obserwując doświadczanie przez dzieci zazdrości lub zawiści, można nie tylko ocenić poziom dojrzałości, ale tego typu sytuacje same w sobie przyczyniają się do rozwoju dojrzałości choćby przez uczenie się rozumienia działania innych ludzi czy nabywanie umiejętności argumentacji. Podobnie

11 L. A. Camras, Dwa aspekty rozwoju emocjonalnego: ekspresja $i$ wzbudzanie emocji, w: Natura emocji. Podstawowe zagadnienia, dz. cyt., s. 290-291.

12 R. Vasta, M. M. Haith, S. A. Miller, Psychologia dziecka, tłum. M. Babiuch, Warszawa 1995, s. 450-451. 
doświadczanie przez dziecko wstydu i zakłopotania może przyczynić cię do rozwoju samoświadomości dziecka i jego refleksji nad osiągnięciami i zdolnościami własnymi i innych. Rozwój emocjonalny polega zatem na zmianie sposobu przeżywania emocji oraz coraz lepszym rozumieniu siebie, innych ludzi i świata społecznego ${ }^{13}$. Do lepszego rozumienia siebie i swoich emocji przydaje się myślenie, czytanie i mówienie o uczuciach. Literatura i film zwłaszcza gdy ich twórcy potrafią dobrze ukazać wnętrze człowieka, jego psychikę i to, co się w niej dzieje - pomagają w rozwoju zdolności obserwacji zachowań własnych i innych ludzi oraz w coraz lepszym rozumieniu siebie i nazywaniu swoich wewnętrznych przeżyć i ich ekspresji ${ }^{14}$.

Rozwój regulacji emocji powoduje nie tylko zdobycie umiejętności: kontroli impulsów, powstrzymywania zachowań wiążących się z emocjami, argumentowania, wyczekiwania i cierpliwości. To również doskonalenie umiejętności wpływania na swoje i cudze emocje. Dziecko osiąga to poprzez wzrost kompetencji komunikacyjnych, dzięki czemu potrafi wyjaśnić własne stany emocjonalne, wyrażać pociechę, ukojenie i miłość oraz przyjmować je od innych. Z biegiem czasu młody człowiek jest coraz bardziej zdolny do mówienia - zwłaszcza rodzicom - o swoich pozytywnych i negatywnych doświadczeniach: o tym, że się czymś cieszy, że coś lubi, że kocha rodziców, potrafi wymyślać coraz to nowe formy zabawy, droczyć się, żartować, dzięki czemu buduje coraz głębsze relacje. Dziecko potrafi też manipulować wyrażaniem swoich emocji w celu osiągnięcia korzyści lub uniknięcia niepożądanych konsekwencji. Dzielenie się z innymi własnymi emocjami, a także coraz lepsze rozumienie emocji innych i zdolność wywierania na nie wpływu przekłada się na możliwość osiągania przez dziecko coraz większej bliskości z innymi ${ }^{15}$.

Okres dorastania jest czasem, w którym emocje i uczucia nastolatków odznaczają się niezwykłą siłą i zmiennością, przybierają skrajne formy: ogromny zapał i głębokie rozczarowanie, wzniosłe ideały i wielki sceptycyzm, miłość, gniew, wściekłość, poczucie winy, smutek i zniechęcenie. Uczucia wypełniające serce chcą się wydostać na zewnątrz. Są wśród nich

13 J. Dunn, Doświadczanie i rozumienie emocji, relacji społecznych oraz przynależności kulturowej, w: Natura emocji. Podstawowe zagadnienia, dz. cyt., s. 295-296. Por. A. Aguilo, Wychowywać uczucia, s. 164-166.

14 A. Aguilo, Wychowywać uczucia, s. 21, 31-32.

15 J. Dunn, Doświadczanie i rozumienie emocji, relacji społecznych oraz przynależności kulturowej, dz. cyt., s. 296-297. 
codzienne troski i zmartwienia, przyjemne i bolesne wspomnienia, pełne zapału plany i sprawiające ból rozczarowania. Przeżywanie tych sytuacji domaga się obecności bliskich osób, rodziny, przyjaciół, którzy będą umieli wysłuchać i rozumieć ten bogaty i złożony świat doznań i przeżyć emocjonalnych. Jednym z zadań okresu dorastania jest uzyskanie przez młodego człowieka właściwego podejścia do relacji między wolnością i obowiązkami. Kiedy nastolatek pokona błędne postrzeganie obowiązków jako przymusu, który pozbawia go wolności, odkrywa, że można pogodzić swoje pragnienia i obowiązki, gdyż szczęście nie polega na tym, że człowiek robi to, na co ma ochotę, ale to, co powinien robić ${ }^{16}$. Ma to szczególne znaczenie w dobie globalizacji, kiedy to zachodzą zjawiska, które są zagrożeniem dla zdrowia psychicznego i kondycji psychicznej młodzieży oraz zakłócają dojrzewanie emocjonalne. Do zjawisk takich należy np. moda na ekstremalne doznania, dążenie do przekraczania granic, co jest niebezpieczne dla życia oraz zdrowia fizycznego i psychicznego. Wczesna inicjacja seksualna wraz z wynikającymi z niej konsekwencjami, eksperymenty z alkoholem, narkotykami i dopalaczami, ryzykowna jazda, wyścigi, popisy, sponsoring i przemoc to sytuacje, które generują silne, nieraz skrajne emocje, skutkujące dążeniem do jeszcze bardziej ekstremalnych doznań, które w końcu przynoszą jednak rozczarowanie, przygnębienie, nudę i niechęć do życia. Innym niebezpiecznym zjawiskiem jest konsumpcyjny i hedonistyczny stosunek do życia, wynikający z zacierania granic między dobrem a złem (relatywizmu moralnego) i szerokiej dostępności produktów, które negatywnie wpływają na emocje, zwłaszcza dzieci i młodzieży. Przemoc i pornografia niszczą zaś zdolność do empatii oraz wsączają w umysły odbiorców nieprawidłowe, szkodliwe wzorce budowania relacji intymnych z drugim człowiekiem. Cyberprzemoc dostarcza jej sprawcom chwilowej rozrywki, wulgaryzmy bawią, a poważne tematy zostają spłycone. Jeszcze innym zjawiskiem, niebezpiecznym dla rozwijającej się sfery emocji, jest obecny w różnych mediach i pod różnymi postaciami swoisty ekshibicjonizm nawet najbardziej osobistych i intymnych przeżyć, przekraczanie granic przyzwoitości i dobrego smaku dla rozrywki, chwilowej sławy lub zysku materialnego ${ }^{17}$. W tym kontekście rola rodziny $\mathrm{w}$ kształtowaniu sfery emocjonalnej u dziecka

\footnotetext{
16 Por. A. Aguilo, Wychowywać uczucia, dz. cyt., s. 170-172.

17 A. Oleszkowicz, A. Senejko, Psychologia dorastania. Zmiany rozwojowe $w$ dobie globalizacji, Warszawa 2017, s. 77-78.
} 
i nastolatka oraz w uczeniu ekspresji emocji jest niezastąpiona. Rodzice jednak sami nie mogą ulec presji niekorzystnych zjawisk społecznych i medialnych i muszą podjąć maksymalny wysiłek w kierunku budowania dojrzałych relacji ze swoimi dziećmi, otwierając się też na świat dziecięcych i nastoletnich emocji, przeżyć, doświadczeń i trudności w formie międzypokoleniowego dialogu.

\section{W kierunku praktycznych zastosowań}

Wiele czynników składa się na prawidłowy proces wychowania dziecka i nastolatka, również w obszarze wychowania emocjonalnego. Właściwa relacja rodziców między sobą, ich dojrzałość osobowościowa, umiejętność dialogu i rozwiązywania konfliktów, postawy miłości, altruizmu, odpowiedzialności - to tylko niektóre z nich. Omówienie ich znaczenia przekraczałoby ramy niniejszego artykułu. Główną uwagę kieruję więc na jeden $\mathrm{z}$ aspektów wychowania emocjonalnego, jakim jest ekspresja emocji i rola rodziny w jej uczeniu. Praktyczne zastosowanie wiedzy psychologicznej polega na dbaniu przez rodziców o aktywne słuchanie dziecka oraz bezpośrednie nazywanie i wyrażanie emocji i uczuć.

Pierwszym elementem dobrego kontaktu jest uważne wysłuchanie dziecka i nastolatka. Warto pamiętać, że nawet pozycja ciała jest tutaj ważna - człowiek słuchający odzwierciedla zachowanie mówiącego również tym, że siedzi w podobny sposób, utrzymuje z mówiącym kontakt wzrokowy, patrzy na niego, powtarza jego gesty, a nawet oddycha w podobny sposób. Dlatego w czasie rozmowy z dzieckiem dobrze jest usiąść podobnie jak ono, powstrzymać się od komentarzy, nie udzielać od razu rad, nie zmieniać tematu. Niezwykle ważne w rozmowie jest danie dziecku odczuć, że rodzic rozumie jego uczucia. Warto mówić np. „Cieszę się razem z Tobą”, „wiem, jak czuje się człowiek, jak jest mu przykro, gdy ktoś go obgaduje”, „widzę, że jest Ci bardzo smutno z tego powodu”. Potrzeba wysłuchania jest tak duża, że należy dziecku pozwolić wypowiedzieć to, co ma do powiedzenia, nawet jeśli się powtarza, mówiąc o tych samych emocjach ${ }^{18}$.

18 B. Białecka, Ty i Twój nastolatek. Poradnik dla rodziców, Poznań 2017, s. 80-81. 
Psychologia komunikacji podpowiada w tym kontekście tzw. aktywne słuchanie. To jedna $z$ trzech wyodrębnionych form słuchania. Pierwszą jest słuchanie bierne, czyli takie, które cechuje się świadomą koncentracją uwagi na odbieranych treściach bez dodawania własnych komentarzy, ocen i replik. Taki model słuchania - charakterystyczny dla wykładu, recytacji, audycji radiowej - może się jednak przydać w słuchaniu dzieci, np. gdy chcą przeczytać na głos ulubioną bajkę. Drugim typem jest słuchanie z zaakcentowaną uwagą, czyli takie, gdy osoba słuchająca bezsłownie komunikuje rozmówcy, że słucha go z zainteresowaniem. Czyni to przez pochylenie się w kierunku rozmówcy, koncentrację wzroku na twarzy mówiącego, gest towarzyszący jego wypowiedzi oraz quasi-werbalne wypowiedzi typu: $m h m$, aha. Gdy osoba słuchająca wykonuje jakąś inną czynność, np. wertuje kartki papieru, rozgląda się po pomieszczeniu, szuka czegoś w telefonie, patrzy w telewizor czy komputer, osoba mówiąca nie czuje się słuchana i nie ma ochoty kontynuować rozmowy. Słuchanie z zaakcentowaną uwagą zawsze jest przydatne, zwłaszcza gdy dziecko prezentuje dłuższą wypowiedź. Najbardziej zaawansowaną formą jest aktywne słuchanie. W prawidłowo zachodzącym procesie takiego słuchania odbiorca w każdej chwili będzie umiał oddać własnymi słowami to, jak zrozumiał wypowiedź rozmówcy. Chodzi tu jednak nie tylko o zrozumienie treści wypowiedzi, ale też o dotarcie do jej warstwy uczuciowej, która towarzyszy wypowiadanym słowom, czyli o zrozumienie tego, co przeżywa mówiący. Werbalizując wypowiedź zwrotną, która zawiera nie tylko treść wypowiedzianych przez nadawcę słów, ale też zauważone przeżycie uczuciowe, odbiorca komunikuje nadawcy, że ten został zrozumiany. Wypowiedź zwrotna formułowana jest najczęściej w postaci synonimu, czyli powtórzenia własnymi słowami istotnej treści wypowiedzi z dołączeniem elementów uczuciowych ujawnionych w trakcie wypowiedzi, np. „Widzę, jak bardzo martwisz się z powodu choroby Twojego kotka". Zarówno dla wychowania emocjonalnego, jak i dla całego procesu dialogu między rodzicami i dziećmi, porozumienia oraz budowania i pielęgnowania więzi międzyosobowych aktywne słuchanie jawi się jako jeden z najważniejszych czynników ${ }^{19}$.

Drugą ważną podpowiedzią psychologii komunikacji jest bezpośrednie wyrażanie uczuć. Polega ono na prostym, jednoznacznym, otwartym nazywaniu tego, co człowiek rzeczywiście przeżywa. Można powiedzieć np.

19 E. Sujak, ABC psychologii komunikacji, Kraków 2018, s. 26-31. 
"cieszę się, , ,jest mi smutno", ,jestem zadowolony”, ,jestem niezadowolony”. Podkreślić trzeba w tym miejscu, że chodzi o przeżycia prawdziwe, czyli o to, co rzeczywiście osoba przeżywa, a nie o to, co powinna przeżywać. Druga uwaga dotyczy konstruowania wypowiedzi w pierwszej osobie, $\mathrm{w}$,ja” realnym, mówiąc np. „ja się denerwuję", a nie - „to mnie denerwuje”20. Tak realizowane komunikowanie się z dzieckiem i nastolatkiem, z akcentem na aktywne słuchanie i bezpośrednie wyrażanie uczuć i emocji, stanowi ważny czynnik sprzyjający wychowaniu emocjonalnemu oraz uczeniu się wyrażania uczuć i emocji, co przekłada się na dobrostan psychiczny oraz budowanie dojrzałych relacji międzyosobowych.

Niniejszy artykuł nie wyczerpuje szerokiej i złożonej tematyki sfery emocjonalnej, może jednak stanowić inspirację do dalszych poszukiwań teoretycznych oraz zastosowań praktycznych w dziele wychowania młodego pokolenia, zwłaszcza dowartościowania pracy nad ekspresją emocji i uczuć.

\section{Bibliografia}

Aguilo A., Wychowywać uczucia, Ząbki 2009.

Averill J. R., Nieodpowiednie i odpowiednie emocje, w: Natura emocji. Podstawowe zagadnienia, red. P. Ekman, R. J. Davidson, tłum. B. Wojciszke, Gdańsk 1999, s. 227-228.

Białecka B., Ty i Twój nastolatek. Poradnik dla rodziców, Poznań 2017.

Camras L. A., Dwa aspekty rozwoju emocjonalnego: ekspresja i wzbudzanie emocji, w: Natura emocji. Podstawowe zagadnienia, red. P. Ekman, R. J. Davidson, tłum. B. Wojciszke, Gdańsk 1999, s. 290-291.

Doliński D., Ekspresja emocji. Emocje podstawowe i pochodne, w: Psychologia. Podręcznik akademicki, t. 2, Psychologia ogólna, red. J. Strelau, Gdańsk 2000, s. 351-368.

Doliński D., Emocje, poznanie i zachowanie, w: Psychologia. Podręcznik akademicki, t. 2, Psychologia ogólna, red. J. Strelau, Gdańsk 2000, s. 369-394.

20 E. Sujak, ABC psychologii komunikacji, dz. cyt., s. 70-71. 
Dunn J., Doświadczanie i rozumienie emocji, relacji społecznych oraz przynależności kulturowej, w: Natura emocji. Podstawowe zagadnienia, red. P. Ekman, R. J. Davidson, Gdańsk 1999, s. 295-296.

Dziewiecki M., Emocje. Krzyk do zrozumienia, Nowy Sącz 2018, s. 15.

Oleszkowicz A., Senejko A., Psychologia dorastania. Zmiany rozwojowe $w$ dobie globalizacji, Warszawa 2017.

Podstawy psychologii. Podręcznik dla studentów kierunków nauczycielskich, red. W. Pilecka, B. Grodkowska, L. Wrona, Kraków 2000.

Sujak E., ABC psychologii komunikacji, Kraków 2018.

Szewczyk W., Rozumieć siebie i innych. Zarys psychologii, Tarnów 2002.

Vasta R., Haith M. M., Miller S. A., Psychologia dziecka, tłum. M. Babiuch, Warszawa 1995.

Zimbardo P. G., R. J. Gerrig, Psychologia i życie, tłum. E. Czerniawska, Warszawa 2002. 